znajduje powszechnego zastosowania. Jednak istnieje perspektywa obniżenia okresu zwrotu energii elektrycznej z kilkudziesięciu nawet do kilku lat, jeżeli zostaną spełnione określone uwarunkowania dotyczące zarówno technologii produkcji, jak i eksploatacji modułów. Wiąże się to $\mathrm{z}$ zastosowaniem ogniw $\mathrm{z}$ krystalicznego krzemu.

Rozdział dziewiaty zostal opracowany w języku angielskim przez Lawrenca L. Kazmerskiego. Autor podejmuje temat technologii ogniw fotowoltaicznych jako punkt zwrotny rewolucji energetycznej.

W analizowanej publikacji w sposób przejrzysty i zrozumiały przedstawiono zlożone problemy, z jakimi boryka się świat w dobie globalnego kryzysu energetycznego. Wzrost populacji świata czy pogłębiający się efekt cieplarniany wywołały kryzys energetyczny, który wymaga wysiłku całej ludzkości w dążeniu do obniżenia zużycia energii z dotychczasowych źródel i szukania takich, które będą w stanie zaspokoić popyt w jak najmniejszym stopniu szkodząc środowisku naturalnemu. W publikacji zawarto wiele ciekawych informacji, które można wykorzystać w zarządzaniu energetyką. Autorzy wiele informacji przedstawiaja w tabelach, wykresach, mapach co daje bardzo przejrzysty obraz omawianych kwestii. W publikacji przedstawiono obecny stan wykorzystywania odnawialnych źródeł energii w Polsce i na świecie, zawarto również prognozy jak będzie rozwijało się zapotrzebowanie na energię z OZE w przyszłości, wskazano na działania, które mogły by pomóc w rozwoju energii z produktów, które są zwykłymi odpadami w gospodarstwie domowym i bariery, które utrudniaja wykorzystanie naturalnych produktów do produkcji bioenergii. Sa to bardzo ciekawe informacje dla wszystkich ludzi znających stan zasobów środowiska naturalnego, jak je wykorzystywać, aby następne pokolenia ludzkości mogły korzystać $z$ dóbr przyrody jak najdłużej.

Autorzy poszczególnych rozdziałów wnikliwie i wyczerpująco charakteryzują wybrane tematy zachęcając czytelnika do szerszego zapoznania się z opisywanymi zagadnieniami. Niewątpliwą zaletą monografii jest jej język, zrozumiały i przejrzysty.

Wojciech STANKIEWICZ

Uniwersytet Warmińsko-Mazurski, Olsztyn

\title{
Peter Warren Singer, Wired for War The Robotics Revolution and Conflict in the Twenty-first Century, Penguin Press, Nowy Jork 2009, ss. 512.
}

Peter Warren Singer jest amerykańskim badaczem studiów strategicznych młodego pokolenia. Jego dotychczasowy dorobek obejmuje zaledwie trzy publikacje książkowe (włączenie $\mathrm{z}$ recenzowana), jednak wszystkie one podejmują nowe, obiecujące tematy, które z czasem weszly do kanonu naukowej debaty na temat konfliktów zbrojnych. Peter Singer specjalizuje się w badaniach zmian zachodzących w charakterze konfliktów zbrojnych na przełomie XX i XXI wieku. Dwie pierwsze monografie jego autorstwa (Corporate Warriors: The Rise of the Privatized Military Industry oraz Children at War), były pionierskimi pracami, poruszającymi temat nowych kategorii uczestników konfliktów zbrojnych, tzn. odpowiednio prywatnych firm wojskowych oraz dzieci-żołnierzy. Oba zagadnienia stały się z czasem przedmiotem żywego zainteresowania oraz debaty, tak naukowej, jak i publicystycznej. 
Najnowsza praca Petera W. Singera dotyka podobnej problematyki. Omawia ona konsekwencje szerokiego użycia systemów bezzałogowych w zastosowaniach militarnych. Autor jest przekonany, iż postępująca ,,robotyzacja” sił zbrojnych (obecnie proces ten dotyczy w pierwszej kolejności sił zbrojnych USA) niesie ze sobą daleko idące skutki dla sposobu prowadzenia oraz samej istoty wspólczesnych i przyszlych wojen. Tym samym publikacja ta wpisuje się w bogaty nurt toczonej od mniej więcej dwóch dekad debaty odnośnie wpływu nowych technologii na sposób prowadzenia współczesnych wojen. Pisali już o tym Alvin i Heidi Tofflerowie w swej książce Wojna $i$ antywojna. W kręgach wojskowych ogromną karierę zrobiła szeroko propagowana w USA koncepcja tzw. rewolucji w sprawach wojskowych (ang. Revolution in Military Affairs - RMA), pod postacią wojny sieciocentrycznej (ang. Network-Centric Warfare-NCW), wykorzystującej najnowsze zdobycze technologii informacyjnych. W recenzowanej pracy Autor skupil się na jednym obszarze nowych, ,rewolucyjnych” technologii wojskowych, pod postacią robotyki. Singer również odnosi się do koncepcji RMA, definiując ja jako sytuację, kiedy ,zostaje wprowadzona nowa technologia lub organizacja, która z kolei tworzy całkowicie nowy model toczenia i wygrywania wojen". W jego przekonaniu upowszechnienie systemów bezzałogowych stanowi szczególny rodzaj takiej rewolucji, gdyż zmiana dotyczy bezpośrednio tego kto prowadzi wojnę (ludzi zastępuja maszyny).

Głównej treści książki nie stanowi jednak opis techniczny nowych, bezzałogowych, systemów uzbrojenia, ale próba oceny politycznych, strategicznych, społecznych i kulturowych skutków ich upowszechnienia. Jak stwierdził sam Autor, poruszana przez niego tematyka jest punktem spotkania wojny, historii, polityki, nauki, biznesu, technologii i kultury popularnej. P. W. Singer zwraca uwagę na to, iż ,robotyzacja” wojska nie będzie tylko kolejnym daleko idącym usprawnieniem taktycznym, ale niesie ze sobą konsekwencje polityczne i społeczne. W kolejnych rozdziałach swej książi poddaje on analizie takie zagadnienia jak: wpływ ,,robotyzacji” na postrzeganie konfliktu, tak przez opinię publiczną (tzw. efekt Youtube), jak i przez samych żołnierzy (redefinicja doświadczenia uczestnictwa w wojnie), nowa demografia konfliktów (obsługa systemów bezzałogowych przez ludzi uważanych do tej pory za zbyt młodych lub zbyt starych, aby walczyć), wpływ nowych technologii na psychologię walki, prawa człowieka czy zasady prowadzenia wojny. Tym samym prezentuje on przekonujace argumenty dla poparcia tezy, iż upowszechnienie wojskowych systemów bezzałogowych, będzie miało rewolucyjne efekty, nie tylko w sferze czysto wojskowej, ale także dla całego politycznego, społecznego i kulturowego podłoża wojen.

Znaczną część pracy stanowi treść opinii, uwag, przemyśleń i anegdot zebranych przez P. W. Singera w trakcie rozmów z wieloma naukowcami, politykami, komentatorami i żołnierzami w różny sposób związanymi z tematem bezzałogowych systemów walki. Autor sam przyznaje, iż posłużył się metodą zapożyczoną z etnografii, w której aby lepiej zrozumieć zagadnienia społeczne zbiera się pojedyncze historie (opowieści) członków społeczności i na ich podstawie układa się szerszą narrację. Początkowo czytelnik może odnieść wrażenie, iż kolejne podrozdziały są nieco chaotycznymi zbiorami luźno ze sobą powiązanych opowieści czy anegdot przytaczanych przez kolejnych rozmówców Autora, jednak poznanie calości wywodu pozwala stwierdzić, iż jest on logiczny, uporządkowany i służy ilustracji jasno zarysowanych tez. Książka jest napisana w bardzo specyficzny sposób, zbliżony w swym charakterze do amerykańskiej publicystyki. Styl jest bardzo swobody, silnie nasycony elementami humorystycznymi i nawiazaniami do kultury masowej. Naraża to 
Autora na zarzuty o brak profesjonalizmu, czy wręcz o nienaukowy charakter publikacji. Należy jednak podkreślić, iż jest to świadomy zabieg, służący celom, które Autor postawil. W opinii P. W. Singera ,robotyzacja” wojny niesie ze sobą na tyle poważne konsekwencje dla całego społeczeństwa, iż zagadnienie to powinno zostać przybliżone możliwie najszerszemu gronu odbiorców. Stąd starania, aby język i styl książki były w maksymalnym stopniu przystępne dla czytelnika nieobeznanego z tematyką nauk wojskowych czy politycznych.

Recenzowana książka jest nietypową pozycją, łączącą w sobie treści naukowe i publicystyczne. Sam Autor przyznaje, iż celem tej publikacji, jest zarówno próba zrozumienia politycznych, wojskowych, społecznych i kulturowych konsekwencji postępującej ,robotyzacji" wojny, jak i zainicjowanie szerokiej debaty społecznej na ten temat. W opinii recenzenta cele te udało się osiągnąć. W kontekście opracowania naukowego wątpliwości może budzić swobodny styl publikacji oraz wyraźnie zarysowane tezy o charakterze publicystycznym. Jednak należy przyznać, iż służy to przejrzystości wywodu oraz przystępności książki dla szerokiego grona czytelników. Peter W. Singer zabrał w swej najnowszej publikacji głos w ważnej dyskusji na temat wpływu nowych technologii na charakter współczesnych konfliktów zbrojnych. Chociaż jego tezy są z pewnością dyskusyjne, to stanowią intrygujący punkt wyjścia dla dalszej debaty. Tym samym Wired for War [...] stanowi niezwykle ciekawą pozycję dla wszystkich zainteresowanych tematyką studiów strategicznych.

Rafał WIŚNIEWSKI

Uniwersytet im. Adama Mickiewicza, Poznań

\section{Terroryzm. Materia ustawowa?, red. Krzysztof Indecki, Piotr Potejko, Agencja Bezpieczeństwa Wewnętrznego Centralny Ośrodek Szkole- nia im. Gen. Stefana Roweckiego "Grota" w Emowie, Warszawa 2009, ss. 186.}

Wydany w 2009 roku przez Centralny Ośrodek Szkolenia Agencji Bezpieczeństwa Wewnętrznego zbiór trzynastu tekstów stanowi pozycję interesującą nie tylko ze względu na charakter wydawcy, znanego raczej z aktywności w dziedzinach innych niż edytorstwo naukowe. Różnorodność tematyki zamieszczonych prac wskazuje, iż redaktorzy opracowania przyjęli za cel możliwe pełną prezentację krajowych badań nad zjawiskiem terroryzmu. Zasadne jest też przypuszczenie, iż publikacja jest skierowana w pierwszym rzędzie do funkcjonariuszy ABW oraz innych służb i ma stanowić pomoc dydaktyczną w ośrodkach szkolenia.

Choć Autorzy zamieszczonych w omawianym zbiorze opracowań związani są z takimi podmiotami, jak: Agencja Bezpieczeństwa Wewnętrznego, Sąd Najwyższy, Ministerstwo Spraw Zagranicznych, Uniwersytet w Białymstoku, Uniwersytet Warszawski, Uniwersytet Lódzki, Uniwersytet im. Adama Mickiewicza w Poznaniu, Biuro Rzecznika Praw Obywatelskich, Dolnośląska Szkoła Wyższa we Wrocławiu, Wyższa Szkoła Przedsiębiorczości i Zarządzania im. L. Koźmińskiego, to - w ujęciu ilościowym - przeważają prace o charakterze prawoznawczym.

Książkę otwiera opracowanie Lecha K. Paprzyckiego pt. Czy Polsce potrzebna jest ustawa antyterrorystyczna? Autor opracowania w barwnym, eseistycznym zgoła stylu, 